\title{
Journal of Sociolinguistics
}

\section{Historicizing Diaglossia}

\begin{tabular}{|r|l|}
\hline Journal: & Journal of Sociolinguistics \\
\hline Manuscript ID & JSLX-15-067.R2 \\
\hline Manuscript Type: & Article \\
\hline Keywords: & $\begin{array}{l}\text { historical sociolinguistics, diaglossia, standardization, Dutch, German, } \\
\text { English }\end{array}$ \\
\hline \multicolumn{2}{|l}{} \\
\hline
\end{tabular}

SCHOLARONE $^{\text {"x }}$

Manuscripts

For review only. Confidential. Should not be cited. 
Historicizing Diaglossia

\begin{abstract}
Auer $(2005,2011)$ presents a typology of present-day dialect/standard constellations in Europe, thereby reintroducing the concept of diaglossia, which refers to a situation with intermediate variants between dialect and standard. Characterizing the sociolinguistic landscape in many languages in Europe today, diaglossia is assumed to be a relatively recent phenomenon dating back to the late nineteenth or early twentieth century, following a previous stage of diglossia. Drawing on a range of case studies of post-Medieval English, German and Dutch, this paper argues that the sociolinguistic situation in the Early and Late Modern period cannot be described in terms of diglossia, and is characterized by a ubiquity of intermediate variants instead, that is by diaglossia. This means that diaglossia should be extended much farther back in time and is not a recent development following a state of diglossia.
\end{abstract}

Key words: historical sociolinguistics, diaglossia, standardization, Dutch, German, English

Short running title: Historicizing diaglossia

Word count: 10,850 
Historicizing Diaglossia

Zusammenfassung

Auer $(2005,2011)$ legt eine Typologie von gegenwärtigen Dialekt/Standard-Konstellationen in Europa vor, wobei das Konzept der Diaglossie für die Beschreibung von Varianten zwischen Dialekt und Standard wiedereingeführt wird. Diaglossie ist heute kennzeichnend für die soziolinguistische Landschaft in zahlreichen Sprachräumen Europas. Auer nimmt an, dass Diaglossie ein rezentes Phänomen ist, das erst Ende des 19. oder Anfang 20. Jahrhunderts eine frühere Phase von Diglossie ablöste. Auf der Grundlage von Fallstudien zum neuzeitlichen English, Deutsch und Niederländisch wird in diesem Artikel argumentiert, dass die soziolinguistische Situation in der frühen und jüngeren Neuzeit nicht als diglossisch beschrieben werden kann, sondern wegen der Allgegenwart von Formen zwischen Dialekt und Standard als diaglossisch konzeptualisiert werden sollte. Diaglossie ist somit kein junges Phänomen, sondern geht wesentlich weiter in der Zeit zurück. 


\section{INTRODUCTION ${ }^{1}$}

Auer (2005) is a groundbreaking paper that presents a typology of present-day dialect/standard constellations in Europe. It reintroduces the concept of diaglossia, which refers to a situation with 'intermediate variants between standard and (base) dialect' (Auer 2005: 22), thus breaking down the dichotomy implied by dialect/standard diglossia. Offering a general description of the sociolinguistic situation in many language areas in Europe today, the concept of diaglossia brings together phenomena often described in terms of regiolectization, destandardization and substandardization. According to Auer (2005: 23), diaglossia is a relatively recent phenomenon dating back to the late nineteenth or early twentieth century, following a previous stage of dialect/standard diglossia. In this paper, I argue that the sociolinguistic situation of many European languages in the Early and Late Modern period cannot be described in terms of diglossia, and is characterized by a ubiquity of intermediate variants instead. This means that diaglossia should be extended much farther back in time. The paper takes up a suggestion made by Dossena (2012: 26-27), and continues the argument of Nevalainen (2012: 130-131), who also claims that diaglossia is a much older phenomenon, and in fact a useful concept to describe the sociolinguistic situation in Late Medieval England.

Section 2 discusses the concept of diaglossia. Referring to intermediate forms located in between base dialects and standard languages, diaglossia depends on the definitions of dialect and standard. The discussion in Auer $(2005,2011)$ mainly revolves around the definition of standard. Following Auer (2011), the standard has three crucial characteristics that can be summarized as follows: it lacks variation, it has prestige and it is codified. Historicizing these three characteristics in Section 3, I argue that they do not apply to the history of European languages, taking examples from the history of English, Dutch and German. The available historical evidence shows that the situation was more complex and cannot be conceptualized as diglossic, with spoken dialects on the 
one hand and a written standard language on the other. Instead, it seems to be much more in line with Auer's description of diaglossia. Section 4 contains the discussion and conclusions.

A few preliminary remarks are in place. As Auer $(2005,2011)$, I focus primarily on dialect/standard continua. The sociolinguistic situation in Medieval and post-Medieval Europe was more complex, however. Multilingualism was widespread; well-known is the importance of French in domains such as international trade and diplomacy. Before endoglossic standards came into use, exoglossic standards such as Latin, Church Slavonic and Arabic were used (Auer 2005: 9), which often remained important after endoglossic standards had developed. ${ }^{2}$ Furthermore, while historical sociolinguists take great pains to find sources that are as close to the spoken language as possible (Elspaß 2012: 156; Nevalainen and Raumolin-Brunberg 2012: 23), all observations and analyses in this paper are necessarily based on written documentation.

\section{DIAGLOSSIA}

In many present-day European language areas, 'the space between base dialect and standard' (Auer 2005: 22) is filled with intermediate forms that are neither distinctly dialectal nor standard. A well-known example is Estuary English (Altendorf 2003). Such intermediate forms enable language users 'to act out, in the appropriate contexts, an identity which could not be symbolised through the base dialects (which may have rural, backwardish or non-educated connotations) nor through the national standard (which may smack of formality and unnaturalness and/or be unable to express regional affiliation)' (Auer 2005: 23). To refer to these intermediate forms, Auer $(2005,2011)$ uses diaglossia and diaglossic reportoire instead of regiolect and regional dialect, because 'the implication [of the morpheme -lect] that we are dealing with a separate variety is not necessarily justified' (2005: 22). Like diglossia, the notion of diaglossia conceptualizes a community's sociolinguistic repertoire at a given place and time. As such, it offers a general description of the varietal spectrum synchronically available to language users without making claims about the 
regional or social origin of the various intermediate forms. In Europe today, diaglossic repertoires are found everywhere, from Norway to Cyprus and from Poland to Spain (Auer 2005).

Auer $(2005,2011)$ presents a typological and historical analysis of the rise of diaglossic repertoires in Europe. The typological development runs from a previous state of diglossia to diaglossia. The diglossic phase is first characterized by an exoglossic standard such as Latin, Church Slavonic or Arabic, and vernacular spoken varieties. This situation is found throughout Medieval Europe. Then there is a transition to a situation with an endoglossic standard, which is structurally related to the vernacular. The rise of endoglossic standards can be traced back to the fourteenth century (Auer 2005: 14). These are first mainly written, later also spoken. The endoglossic standards subsequently make their way into the spoken language, a phase which Auer (2005: 17) locates in the Early and Late Modern Period, between the fifteenth and the nineteenth century. Next, diaglossia may develop from the situation with an endoglossic standard roofing the spoken dialects, for example through dialect-to-standard advergence or through destandardization, in which case regional elements are increasingly tolerated in the standard (Auer 2005: 25). The emergence of diaglossic repertoires is considered to be 'a relatively late phenomenon, usually of the late nineteenth or early twentieth century' (Auer 2005: 23).

In this analysis of European dialect/standard constellations, dialect is a 'a purely relational concept' (Auer 2005: 7). Auer (2011: 487) describes dialects as 'the varieties under the roof $\ldots$ of a standard variety which preceded the standard languages and provided the linguistic material out of which the endoglossic standard varieties developed'. 'More controversial' (Auer 2005: 8) is the definition of standard, which has three characteristics that are introduced in Auer (2005) and rephrased in Auer (2011):

1. The standard 'is orientated to by speakers of more than one vernacular variety (which does not necessarily mean that it is mastered by everybody)', according to Auer (2005: 8). In Auer (2011: 486), this is rephrased as follows: the standard 'is a common language, i.e. 
one which (ideally) shows no geographical variation in the territory in which it is used'. Although this new definition is hedged by the insertion of ideally, it appears to be more restricted than the 2005 definition, which explicitly leaves room for variation because not all speakers/writers are assumed to master the standard - they are merely assumed to orient themselves to it. The 2005 definition also suggests that variation within the standard may be explained away by assuming different degrees of adhering to the standard. Such a unidimensional conceptualization of sociolinguistic space has been criticized in the sociolinguistic literature (see under 2).

2. The standard 'is looked upon as an H-variety and used for writing' (Auer 2005: 8). Auer (2011: 486) says that the standard 'is an H variety, i.e. it has overt prestige and is used in situations which require a formal way of speaking (if a spoken standard exists at all), as well as in writing. The second criterion is more narrow as well, in that it explicitly mentions prestige, a notoriously difficult notion (Milroy 1992), if only because the standard's apparent prestige does not generally lead all speakers/writers in a specific community to abandon their non-standard usage and shift to the standard. As Auer (2011: 486) acknowledges, non-standard varieties may show covert prestige, but here the difficulty is that the value attached to non-standard varieties 'is often far from covert' (Meyerhoff 2011: 42). What is more, standard varieties are often looked upon as distant or artificial, while local varieties may carry 'strong notions of naturalness and straightforwardness' (Meyerhoff 2011: 41).

3. The standard 'is subject to at least some codification and elaboration ... or Ausbau' (Auer 2005: 8). Here, reference is made to Haugen (1966) and Kloss (1967). Auer (2011: 486) rephrases this characteristic as follows: the standard 'is codified, i.e. "right" or "wrong" plays an important role in the way in which speakers orient towards it'. Again, the definition is slightly more restrictive than in 2005 , shifting emphasis from 'at least some codification' to plainly 'codified'. The appeal to 'right' and 'wrong' is somewhat dubious, 
as it is well known that similar ideas about correctness or appropriateness exist with regard to non-standard varieties. Dense and multiplex social networks, for example, tend to preserve non-standard variants and to lead speakers to use these non-standard variants, despite the higher status of standard variants in the wider speech community (Milroy 2002; Milroy and Milroy 2012: 48-51). At the same time, the 2011 definition lacks the elaboration or Ausbau element of the 2005 definition, perhaps because many of the present-day European standard languages cannot be said to still undergo elaboration and Ausbau.

The three characteristics of the standard are more narrowly defined in Auer (2011) than in Auer (2005), leaving less room for geographical variation, and emphasizing that the standard is prestigious and codified. Nevertheless, Auer (2011: 486) says that these three features of standard languages are gradual, which implies that 'the process of standardisation may be more or less advanced depending on how precisely the above criteria are met'. The formulation indicates that, along the lines of Milroy and Milroy (2012), standardization is understood as a historical process, the ultimate aim of which, viz. uniformity (cf. Auer's first criterion), is never fully realized, except, of course, in dead languages (Milroy and Milroy 2012: 19). The inherent gradualness of the three criteria, however, and the fact that standardization is thought of in historical terms, raises the question of at what point in time the criteria have been sufficiently met. When do we find historical stages of European languages that somehow convince us that we are dealing with a standard language in accordance with the aforementioned criteria? The vast body of historical sociolinguistic work carried out over the past few decades may help find an answer to this question.

\section{DIAGLOSSIA IN HISTORY}


Much historical sociolinguistic work has focused on the the Early and Late Modern Period, when according to Auer's historical scenario European dialect/standard constellations were characterized by diglossia, with spoken dialects on the one hand and endoglossic standard languages on the other. In this section, I argue that the Early and Late Modern Period displayed a much wider range of variation with many intermediate forms in between dialect and standard, and should therefore be characterized as diaglossic instead. Delving into Auer's three characteristics of standard languages discussed in section 2, I argue that neither the relatively lax 2005 nor the more restrictive 2011 definitions are in line with some crucial observations made in the field of historical sociolinguistics. The first two characteristics, viz. lack of variation in the standard and its prestige, will be discussed in 3.1. Case studies of Early and Late Modern English, Dutch and German show that regional, social and register variation were considerable. In addition, there were writing conventions that were not in line with the presumed contemporary standard, which means that not all writers oriented themselves to the same set of norms. Section 3.2 continues the theme of multiple and variable norms for writing by discussing two relevant and related concepts from the research literature, viz. supralocalization and intended supralocal variety. Section 3.3 discusses codification, the third characteristic of the standard.

\subsection{Regional, social and register variation}

Auer (2005: 14-18) says that the spread of standard languages over the language areas in postMedieval Europe depended a.o. on regional and social factors. As a consequence, variation was an inherent aspect of the incipient standards. In those cases where a spoken standard developed out of a preceding situation with a written standard and spoken dialects, codification needed to be extended to a new domain, viz. speech, which was not codified in writing and 'difficult to enhance in a large area' (Auer 2005: 16). Auer goes on to argue that codification of speech has often remained imperfect, and that nowadays spoken standard languages generally display more inherent variability than written standard languages. In this section, I will argue that there is more 
to the variation found in written sources from the past than only the relative success to which standard norms are adhered to. The case studies reported on are founded on sources relatively close to the spoken language, such as private letters. It is important to point out beforehand that these do not display transliterated dialect (Elspaß 2007: 152; Rutten and van der Wal 2014: 73). They are written in an at least partially deregionalized variety, an issue that I will return to in 3.2.

\subsubsection{Regional variation}

Many studies demonstrate the existence of regional variation in the written language of the Early and Late Modern period. I will give examples of regional writing practices in English and Dutch up to 1700, and in English, Dutch and German of the eighteenth and nineteenth centuries. The examples demonstrate that different writing conventions often co-existed, indicating a plurality of 'standard'-like norms reminiscient of a state of diaglossia.

\section{English and Dutch before 1700}

Nevalainen and Raumolin-Brunberg (2003: 157-184) discuss fourteen grammatical changes on the basis of the Corpus of Early English Correspondence (CEEC, see www.helsinki.fi/varieng/CoRD/corpora/CEEC/index.html), which spans the period from c. 1410 to 1681 . Most of these fourteen variables show clear regional patterns. The replacement of the subject form ye by you, for example, was a change that was led by the capital region. In the years $1520-1559$, in particular, the proportion of you is c. $40 \%$ in letters linked to London and the Court, while it is used less than 15\% of the time in East Anglia and the North (Nevalainen and Raumolin-Brunberg 2003: 172). The replacement of the third-person singular indicative suffix -th by $-s$, on the other hand, spread from the North, where the incoming variant was already dominant in the mid-fifteenth century, while it only became the main variant in London and at the Court by the end of the seventeenth century (Nevalainen and Raumolin-Brunberg 2003: 178). Interestingly, there is a dip in the frequency of $-s$ in the early sixteenth century, which Nevalainen 
and Raumolin-Brunberg explain with reference to the simultaneous spreading of the southern form $-t h$. This means that the two variants were in competition over a considerable stretch of time, and that we are witnessing, in the written language, two concurrent and conflicting processes of supralocalization, referring to the regional spread of linguistic features beyond their region of origin (see 3.2 for further discussion). In the case of - th and $-s$, two features originating in different regions of England are simultaneously spreading to other regions than where they were native.

Similar results have been found for Early Modern Dutch. Nobels (2013: 163) discusses the ending of first-person singular indicative verb forms in seventeenth-century Dutch, using a large corpus of private letters dating back to the 1660s/1670s, the Letters as Loot Corpus (see brievenalsbuit.inl.nl). In Middle Dutch, first-person singular indicative endings were generally characterized by schwa as in ik neeme 'I take', which gradually gave way to a zero ending (ik neem). In the seventeenth century, this change was in full swing. The incoming variant is dominant with c. $70 \%$ zero forms in both the northern and the southern parts of the province of Holland, in towns and cities such as Amsterdam and Rotterdam. In the Zeeland area, however, which borders on the southern parts of Holland, the pattern is reversed and final schwa is retained in c. $70 \%$, testifying to completely different writing conventions. There is an obvious link with the spoken language, since Zeeland and the south-west of the Dutch language area generally tend to retain final schwa in many positions up to the present day, but what is at stake here is that the written language in this period displays massive geographical variability when it comes to verbal inflection.

Another example of regionally-bound variation in seventeenth-century Dutch concerns diminutive formation, where the broad historical development runs from velar forms in -ke (from -kijn) such as briefke 'small/short letter' to palatal forms such as briefje and briefie. In this process of palatalization, which is sometimes assumed to have spread from the north to the south, suffixes such as -ge and -che (e.g. briefge, briefche) represent an intermediate stage (Marynissen 1998). Nobels

For review only. Confidential. Should not be cited. 
(2013: 189-224) analyzes diminutive forms in the Letters as Loot Corpus, discussing dozens of orthographically different diminutive suffixes (Nobels 2013: 193-195). After categorization of the many variants into groups of palatal, velar and intermediate forms, it turns out that all regions for which she has sufficient data display this extremely wide variety of forms, but also that palatal suffixes are dominant in the northern parts of Holland, while velar suffixes constitute the majority in Zeeland. The southern parts of Holland are the only area where the intermediate forms occur quite often, and are even dominant (Nobels 2013: 204).

\section{English, Dutch and German (eighteenth and nineteenth centuries)}

Similar examples can be found in the Late Modern period. Fairman's (2007a, 2007b) studies of eighteenth- and nineteenth-century English pauper letters show that there was an extreme pool of variation, extending well beyond what could be regarded as variation within a relatively uniform standard. Vandenbussche (2004), Vosters and Vandenbussche (2012) and Vosters et al. (2014) show that there was also considerable variation in Dutch writings from the early nineteenth century, which can partly be explained with reference to geography. Interestingly, their data comprise administrative and legal documents. The persistence of regional variation, even in the official domain, raises questions about the feasibility of diglossia to describe the sociolinguistic repertoire. With so many regionally-conditioned intermediate variants at hand, diaglossia seems a more apt general description of the contemporary varietal spectrum.

With regard to the nineteenth century, the most extensive study of language variation and change on the basis of private letters is probably Elspaß (2005). One case study concerns the use of the comparative particle (Elspaß 2005: 284-292). The broad development in High German is often characterized as running from denn 'than, then' as in besser denn 'better than' to als 'as' as in present-day standard High German besser als. Both in historical texts and in present-day dialects, other variants are found, including wie 'how' and als wie 'as how'. Using a large corpus of nineteenth-century private letters, mainly written by emigrants to the United States, Elspaß finds 
all four variants. Diving into their regional distribution, two things stand out. First, that some regional patterning can be discerned, indicating regional writing practices (Elspaß 2005: 288).

Secondly, and even more importantly, that the regional distribution is not entirely in line with the situation in present-day dialects, with, for example, wie and als wie being used by writers from the northern and western parts of the German language area, whereas als is clearly dominant and often the only variant in present-day dialects (Elspaß 2005: 288-291). Moreover, many writers used multiple variants, including one school teacher who used all four options in two letters from 1858. This leads Elspaß to assume that there were supralocal writing conventions that differed both from local dialects and from the prescribed language of the time (Elspaß 2014).

A similar case in point is diminutive formation, where the broad development in the eighteenth and nineteenth centuries runs from -gen to -chen; compare the attested form Metgen (1858, cf. Elspaß 2005: 344) and present-day standard High German mädchen 'girl'. Elspaß (2005: 344-345) argues that the many instances of 'non-standard' -gen in his nineteenth-century corpus, particularly in letters linked to the (north-)west of the language area, cannot be interpreted as interference from the spoken language as this is a purely orthographical variable. Instead, the persistent use of -gen signals a writing convention that continued to be transmitted from generation to generation, despite the fact that -chen had become the 'standard' form decades before. A third example of variation in the written language that appears to be first and foremost the result of different writing conventions concerns the use of final $-e$ in the first and third person singular of strong verbs as in ich sahe 'I saw' and er sahe 'he saw' (Elspaß 2005: 345-348). Again, there is no reason to assume that this ending represents dialect interference, while it had also virtually disappeared from printed texts by the nineteenth century (Elspaß 2014).

The examples demonstrate that the attested regional variation and regional writing practices can only partly be explained with reference to local or regional spoken varieties. Forms were used in writing that did not comply with contemporary prescriptions, but that were also not immediately linked to the writers' spoken vernacular. They are, in other words, intermediate 
forms indicative of a diaglossic repertoire. In the same vein, McColl Millar (2012), analyzing English private letters from the first half of the nineteenth century, argues that many of the linguistic features found in the documents are not in line with the standard of the time. However, they cannot simply be considered dialectal. Features such as the variable use of $b$ in initial position (I ham), the variable use of $r$ (Brothe, farther 'father'), multiple negation (he never send no word to them) and a-ing progressives (you was a speaking) are not localizable in Lancashire, where the writers in his letter collection came from (McColl Millar 2012: 170-173).

An interesting example of intermediate, i.e. non-dialectal and non-standard forms can also be found in eighteenth-century Dutch, viz. deletion of final $n$ in unaccentuated syllables in forms such as brieven [brivə] 'letters', wij lopen [weI lopə], gelopen [xəlopə] 'walked' (Simons and Rutten 2014). Almost systematic deletion is characteristic of the spoken language in large parts of the language area, including Holland, as well as in present-day standard Dutch. Final $<\mathrm{n}>$ is prescribed in standard orthography, and has always been part of writing conventions throughout the language area. Both in the southwest and the northeast, however, little or no deletion occurs in the present-day spoken language. When investigating final $n$ in the eighteenth-century part of the Letters as Loot Corpus, which comprises private letters from the 1770s/17780s, Simons and Rutten (2014) found that letters from the northeast did contain the least instances of deletion, viz. $21 \%$ (as opposed to $30 \%$ in Holland). But 21\% deletion is quite surprising considering that fact that deletion is virtually absent from the spoken language today, especially against the background of the strong tradition of spelling final $n$. Again, we are dealing with a 'non-standard' phenomenon which can, however, not simply be explained with reference to dialect interference. The case is similar to the German examples taken from Elspaß $(2005,2014)$. There appears to be a supralocal writing convention that is neither in line with the current standard nor with the local vernacular: it represents an intermediate stage and points to a diaglossic repertoire.

\section{Summary}


The English, Dutch and German examples presented so far demonstrate that regional variation was a common phenomenon in the written language of post-Medieval western Europe. The line of reasoning applies to other European languages, too; for French, for example, similar arguments have been made (Ayres-Bennett 2014, Lodge 2014, Martineau and Tailleur 2014 and the references there). The supposedly standard forms were not necessarily the most common forms. Moreover, there was not just regional variation in the adoption of 'standard' forms. There were also different regional writing conventions. These were not sets of conventions strictly bound to specific regions, and they should not be thought of as separate regional varieties. Their regionality varies with the linguistic feature under discussion. In sum, writers did not orient themselves to the same norms.

\subsubsection{Social and register variation}

So far, I have focused on regional variation, since geography plays such an important role in Auer's characteristics of the standard language. There is also a wealth of research on social variation in the past. Obviously, the existence of social variation is a complicating factor, diminishing the feasibility of the concept of a standard language when talking about European language history - all the more so when the standard is thought of as free from variation.

Adopting the broad social categories from the variationist tradition such as rank, age and gender, research into social variation in the past has demonstrated significant differences between men and women, and between various social groups in terms of access to socio-economic resources. Extensive analyses, for example, have been carried out by Nevalainen and RaumolinBrunberg (2003) with regard to fifteenth, sixteenth and seventeenth-century English, and by Rutten and van der Wal (2014) with regard to seventeenth and eighteenth-century Dutch. Nevalainen and Raumolin-Brunberg (2003: 110-132) investigate gender effects on fourteen changes in the history of English. Eight changes were led by female writers, among which the replacement of subject ye by you in the sixteenth century, the replacement of the possessive 
determiners mine and thine by my and thy in the sixteenth and seventeenth centuries, and the replacement of - th by $-s$ in the third person singular in the sixteenth and seventeenth centuries.

The results show that women often led processes of language change in the past, too, particularly when the changes emerged from below the level of social awareness (Nevalainen and RaumolinBrunberg 2003: 131).

Rutten and van der Wal (2014), when discussing apocope of final schwa in first person singular present tense indicatives, i.e. the replacement of ik neeme by ik neem 'I take' in seventeenth- and eighteenth-century Dutch, demonstrate the variable effect of social rank and gender, depending on time and region. In seventeenth-century Amsterdam, for example, upperclass men were the most conservative writers and in fact the only social group preferring final schwa. Differences between social ranks were also established for the southern parts of South Holland, but not for the even more southern region of Zeeland, where the changes was just taking off. In the eighteenth century, awareness of the ongoing change led ever larger groups to cling to the historic forms. Upper-middle class writers, including women, now stuck to final schwa, too, both in Holland and in Zeeland. Meanwhile, upper-class men, particularly in Amsterdam, switched to schwa-less forms and suddenly became the most progressive group, adopting a new writing convention, and distinguishing themselves from the still conservative practices found in the upper-middle ranks.

The examples demonstrate that different social groups adopted different sets of norms, testifying to a sociolinguistic repertoire that is more complex than dialect/standard diglossia. Turning to register variation, it becomes clear that intra-writer variation is yet another complicating factor. The notion of register adopted here corresponds to Biber and Conrad's (2009: 4-11), who stress the importance of the situational context for the choice of linguistic variants. So far, my examples were mainly morphological and phonological. It is, however, often assumed that standardization begins with spelling convergence. The relatively uniform (but see below, section 3.3) spelling practices in print language should not lead us to think that there was a 
uniform orthographical code at large in the Late Modern period. Osselton (1984: 125) already drew attention to the 'dual standard of spelling', one public, one private, found in the writings of eighteenth-century men of letters such as Dr Johnson, Addison, Pope and Swift, who all adhered to a similar system in their public writings, while employing another system in their private letters. Osselton (1984: 129) remarks that 'traditional accounts of how English spelling developed historically have focused on the rise of one standard, not a variety of standards'. In more recent years, numerous studies have confirmed the variability of the language of eighteenth-century elites, in orthographical practices but also in the fields of morphology and morphosyntax. Three recent examples are Sairio (2009), Fens-de Zeeuw (2011) and Henstra (2014). Interestingly, Fensde Zeeuw (2011) focuses on Lindley Murray, a well-known eighteenth-century grammarian who in his writings did not always follow the strictures laid down in his own grammar. Despite the image of the eighteenth century as the age in which English was normalized, made uniform and codified, these studies show that this idea cannot be maintained. Even Robert Lowth himself, the alleged icon of English prescriptivism, did not adhere to his own rules of grammar in his private writings (Tieken-Boon van Ostade 2011: 183-184). The evidence presented in these and similar studies shows that there were situational constraints on the choice of variants, depending on the medium (letter vs published work), the audience (private vs public) or the social relationship between writer and addressee (cf. Nevalainen and Raumolin-Brunberg 2003: 189-200; Nevala 2004).

\subsection{MULTIPLE AND VARIABLE NORMS FOR WRITING}

Auer's second criterion of standard languages says that they are H-varieties used for writing (section 2). This is probably true of much of the official communication in present-day Europe, and it equally applies to the domains of mass media, especially traditional newspapers, and literature. It is also obvious that it does not apply to informal written communication, particularly as it is found in more recent private and mass media such as msn, sms, chatrooms, whats-app, 
Facebook and so on (e.g. Schlobinski 2005; Androutsopoulos 2006). With regard to history, it could perhaps be argued that the language of formal genres including official/administrative texts, literary texts and academic prose meets this criterion. As the data presented in 3.1 suggest, however, it is not obvious that the average language user considered the language of these relatively formal genres as an $\mathrm{H}$-variety, let alone a variety that should be adopted in writing. As argued in 3.1, there were multiple and sometimes divergent writing practices, some of which converged to or were identical with the supposed $\mathrm{H}$-variety, while others were not. This means that Early and Late Modern communities exhibited diaglossia to the extent that intermediate variants, located between the base dialect and the supposed standard, abound.

In this context, two related notions from the historical sociolinguistic literature are relevant, viz. supralocalization and intended supralocal variety. Supralocalization goes back to earlier work such as Milroy, Milroy and Hartley (1994), where it is argued in the context of present-day English that 'linguistic variables operate at different levels of generality in terms of their territorial spread' (1994: 2). Some variants are highly localized, others characterize a somewhat wider region, others have an even wider spread, creating a broad opposition of northern and southern British English, and still others occur in the whole English-speaking world. These observations are used to argue that we need to move beyond 'the simplistic opposition between standard and non-standard' and that we should adopt 'an approach that recognises gradations in terms of local and non-local' (Milroy, Milroy and Hartley 1994: 2). The argument ties in with Auer's (2005) summary description of the development of regiolects and diaglossia in Europe today. Supraregionalization as described by Hickey (2012) essentially refers to the same phenomenon of varieties of a language losing certain localizable features and becoming less regionally bound. Drawing on studies such as Milroy, Milroy and Hartley (1994), Nevalainen and Tieken-Boon van Ostade (2006: 288) describe supralocalization as 'an umbrella term to refer to the geographical diffusion of linguistic features beyond their region of origin' in the history of English. Whereas diaglossia and diaglossic repertoire are general descriptions of the 
sociolinguistic situation at a given place and time, supralocalization centers round the trajectory of individual linguistic forms.

The shift away from the local and the localizable as implied in the concept of supralocalization raises the question of its relationship to standardization. Nevalainen and Tieken-Boon van Ostade (2006: 288) argue that 'standardisation is often facilitated by the prior development of suitable supralocal norms, being as it were, superimposed upon them'. Similarly, Joseph (1987) distinguishes between language standards and standard languages, where the former refers to the multiple and sometimes conflicting supralocal norms for writing developed in European language histories from the earliest days onward, the latter to the more or less uniform standard languages of the present. One of the most important research goals in standardization studies, Deumert and Vandenbussche (2003: 456) argue, is to clear up the interaction between 'pre-existing language standards and the emerging standard language'. Standardization, then, is generally preceded by a period of multiple and variable norms for writing, that is, by co-existing instances of supralocalization. Such a shift away from strictly local features is not necessarily a shift towards uniformity (Milroy, Milroy and Hartley 1994; Hickey 2012). Supralocalization does not necessarily imply standardization. This is clear from some of the examples presented in the previous section, where it was argued that there were writing conventions that were neither localizable nor in line with the contemporary standard. Nevalainen and Raumolin-Brunberg (2003: 183), who investigated processes of supralocalization in English texts dating back to the fifteenth, sixteenth and seventeenth centuries, conclude that 'supralocalizing features do not have any single path of transmission ... it is individual linguistic features rather than fully-fledged varieties that get selected, accepted and diffused across the country' [emphasis in the original]. While writers may have an idea about a H-variety, or at least about a preferred form for writing at the level of individual variables, this idea is not necessarily similar for all of them nor is it analogous to the supposedly standard language of the time. 
Various instances of supralocalization may coexist, with or without one of these being promoted to the standard form.

The second notion from the historical sociolinguistic literature that is helpful here is intended supralocal variety. The notion of an intended supralocal variety was developed in German historical sociolinguistics (intendiertes Hochdeutsch, cf. Mihm 1998) and is used to refer to a variety which does not meet the formal requirements of a standard language (e.g. consequent spelling and grammatical soundness), but which is nevertheless intended by the writer to fulfil the functions attributed to a standard variety (e.g. supra-regional communication, prestige variety). The term refers, accordingly, to the functional value of a variety in the eyes of the writer and cannot be defined in fixed formal terms' (Vandenbussche 2004: 30-31; cf. Rutten and van der Wal 2014: 74, 406). The crucial distinction here is that between form and function. Whereas standardization is often referred to as (the strive for) minimal variation in form, the concept of an intended supralocal variety is restricted to the functional side. Language users adopt forms that are meant to function supraregionally. The concept of an intended supralocal variety is essentially a negative one. Language users do not aim to use the one standardized or prescribed form, if there is such a form. Instead, they render their language less localizable by adopting lesslocalizable forms, but these can be of any kind - as long as they are less-localizable. By implication, writers do usually not aim to produce transliterated dialect. 'As a matter of fact,' Vandenbussche (2004: 21) adds, "the formal character of this "intended standard language" will be different for each writer since it is the highest variety mastered on his personal continuum between dialect and standard language'. Again, this means that we have to reckon with multiple and variable moments of de-localization, and that the norms developed in usage need not be uniform, but just not localizable.

The notion of an intended supralocal variety constitutes the writer-oriented and functional side of supralocalization, which is primarily focused on the trajectory of the linguistic forms themselves. At the level of the community's sociolinguistic repertoire, the Early and Late 
Modern period can be called diaglossic, because linguistic variants exibited different levels of supralocalization, and because writers did not always adopt the same set of norms, although most of them aimed at de-localization. The issue of norms is continued in the next section.

\subsection{CODIFICATIONS}

The third criterion identified by Auer deals with codification and ideas about right and wrong. Codification is perhaps one of the most conspicuous aspects of the sociolinguistic situation in post-Medieval Europe. From the fifteenth century onward, spelling guides, schoolbooks, grammars and dictionaries of vernacular languages began to appear. Such publications, which were followed by other grammar books in subsequent centuries, are often considered milestones in the standardization of the languages in question.

A first crucial observation - perhaps a commonplace to many but all too often too easily passed over - is that the norms and prescriptions laid down in orthographies and grammar books were usually far from uniform (e.g. Poplack et al. 2015). Grammarians and other language commentators proposed different systems of prescription, these varying prescriptions were often in competition with each other, and where prescriptions are in competition, there can be no consensus about what is right and what is wrong. Put differently, Auer's (2005: 8) remark that the standard is subject to 'some codification' is quite appropriate in the sense that efforts at codification characterize the Early and Late Modern period, as long as it is understood that these efforts were multiple and diverse, and moreover changed over time. Codifications is the most suitable term when talking about the sixteenth and early seventeenth century. Also later on, when there is often more agreement among grammarians, normative diversity prevails. Langer (2014), for example, discusses stigmatization in eighteenth-century German, while indicating the variability of some of the most stigmatized features, such as the diminutive suffix. There was competition between -chen and -lein in the written code, with -lein gradually becoming stigmatized as regional (Southern) and/or outdated. Towards the end of the eighteenth century, however, 
Adelung, one of the well-known proponents of normative grammar, in his Deutsche Sprachlehre (1782) still preferred -lein in specific registers. An interesting example is also Schottelius, the famous codifier of seventeenth-century German, who did not comment on the (un)acceptability of polynegation and even listed examples such as mit nichten nicht as emphatic negations, while nevertheless eliminating a handful of polynegations in more recent editions of his grammar (McLelland 2014). Finally, ideas about right and wrong may change over time under the influence of changing political and sociohistorical circumstances (e.g. Rutten and Vosters 2013).

As noted above (section 3.1), grammarians, including notorious prescriptivists such as Lowth and Murray in eighteenth-century England, did not always follow their own prescriptions. Apart from that, grammarians sometimes dealt with variation by relegating the variants to different styles, adopting this concept from the rhetorical tradition. Lowth, for example, in his Short introduction to English grammar (1762) distinguished between different styles of speech and writing, which are characterized by different linguistic requirements. Preposition stranding as in Horace is an author, whom I am much delighted with, a verb form such as has and the indicative were more suited to the so-called familiar style, whereas pied piping (viz. with whom instead of whom ... with), hath and the subjunctive were more appropriate to the solemn and elevated style (TiekenBoon van Ostade 2011: 183-184). Such distinctions recall Osselton's remarks on the dual standard of spelling in eighteenth-century England (section 3.1) and Adelung's preference for lein-diminutives in specific registers.

In the Dutch language area, Lambert ten Kate is well-known for his analysis of variation in terms of stylistic differences. In his 1723 Aenleiding tot de kennisse van het verhevene deel der Nederduitsche sprake 'Introduction to the knowledge of the sublime part of the Dutch language', he adopted the familiar, polite and elevated style from the rhetorical tradition. He then distributed grammatical variants over these stylistic levels. In the case of nominal inflection, for example, at a time when spoken Dutch was characterized by the almost complete loss of inflectional endings, he prescribed synthetic case endings in the elevated style and periphrastic constructions with 
prepositional phrases in the familiar style. The polite style took a middle position, often siding however with the familiar style (Rutten 2012). This kind of sensitivity to differences between styles or registers, which implies varying norms depending on situational conditions, is not often seen as a crucial part of eighteenth-century metalanguage. In many European language areas, the period is often cast in terms of increasing uniformity and normativity, and of intensified codification and prescription (cf. the chapters in Rutten, Vosters and Vandenbussche 2014). Nonetheless, we have to reckon with multiple codifications, and with the context-dependency of notions of right and wrong. Also from the perspective of codifications, therefore, the multiplicity and variability of norms evidences diaglossia rather than diglossia.

The context-dependency of codifications can be taken even one step further. Nevalainen (2014), discussing language norms in seventeenth-century England, notes that we need to think about language norms in terms of their target groups. In the seventeenth century, these were often quite restricted, with English grammars being targeted towards either foreigners, typically merchants, or schoolboys, on the assumption that the acquisition of Latin would be easier when grammatical terms and concepts had first been learnt via English. It is only with the rise of the middle classes in the eighteenth century that a new ideology came into being, at the core of which lies the idea that upward social mobility depends on language skills, i.e. on the ability to use the 'standard' (Beal 2004). Moreover, this new middle class was subsequently ready to accept all the social prejudices inherent in a unified, exclusive standard (Hickey 2010).

Increasingly, standard language norms became essential and defining factors in the creation (or appropriation) of a specific social and educated identity. The new genre of the usage guide resulted from this development (Tieken-Boon van Ostade 2014).

Langer (2014) points to a similar development in eighteenth-century Germany, where a social split arose between those with access to supraregional High German and those without, which distinguished the lower classes on the one hand, and the middle and upper classes on the other. A widening of the target audience of metalinguistic discourse can also be discerned in the 
history of Dutch (Rutten 2012). The decisive turning point can be located in the second half of the eighteenth century, when the literary and elitist orientation of the earlier decades of the century is abandoned in favor of an inclusive approach to language, underpinned by a nationalist ideology.

What is crucial in Late Modern Dutch, English, French and German (cf. Rutten, Vosters and Vandenbussche 2014), is that the target audience of metalinguistic publications changed from identifiable groups such as socio-cultural elites into the nation as a whole.

Normalized language changed from a tool for specific situational purposes into a central issue of education for the entire population. At the same time, language planning changed from one out of many socio-cultural occupations into a core element of the socio-political construction of national identities. As Burke (2004: 166) comments, language underwent 'nationalization'. Efforts at codification, in other words, should be interpreted socially, taking into account the target audience of linguistic prescriptions and proscriptions. In many language areas, it is only from the late eighteenth century onward, with the advent of the modern nation-states, that adherence to a defined and uniform set of standardized norms is expected from all language users, and that such a set of norms is therefore taught in schools. What is being codified in earlier publications is often only a specific variety for special purposes, to be used only by certain language users in specific contexts. This means that it is questionable to what extent such a variety can be considered 'the roof' of a collection of genetically related spoken and written varieties.

Finally, new ways of analyzing the traditions of codification and prescriptivism have come into being. As argued a.o. by Lodge (2013) and Ayres-Bennett (2014) with regard to seventeenth-century French, there is a need to move away from the view that linguistic commentators such as the remarqueurs were strictly prescribing the forms that language users should adopt, or that they were linguistic legislators. Both Lodge (2013) and Ayres-Bennett (2014) suggest that the remarqueurs were often merely reflecting usage, and that they were keen observers of changing usage. They interpret the metalinguistic position taken by Vaugelas and

For review only. Confidential. Should not be cited. 
others within a sociohistorical framework of urbanization and social mobility, where the plurality of linguistic forms found in interaction is dealt with through the attachment of social values to particular forms. The remarqueurs observed and recorded such processes of value attachment. The implication is that a top-down view of the linguistic situation, with prescriptivists prescribing the forms that language users should adopt, does not offer an accurate description of sociolinguistic space in history. Language norms were not developed on the one side and then transmitted to the other side. Instead, normative works were part of the same field where languages users as well as language observers engaged in norm negotiations. As such, the call for a more nuanced and much richer description of the sociolinguistic situation resembles Milroy's (1992: 147) argument against 'a conceptualization of sociolinguistic space that is unidimensional - a space in which the elite groups set the tone in language, dress and other cultural matters, and in which lower groups strive to imitate their lead'. For Milroy, the core of the argument is that language users often do not follow the elite variety, and that linguistic changes often do not originate in the alleged prestige variety. From the elite perspective, however, a similar line of reasoning criticizing the unidimensional prestige model applies, in that language commentators were not always involved in a simple act of prescription, but were taking stock of the various linguistic forms that were around and the social values connected to them. Therefore, Early and Late Modern dialect/standard constellations were not just diaglossic rather than diglossic because of the multiple and variable norms for writing attested in usage, but also because normative discourse itself was varied and variable.

\section{DISCUSSION AND CONCLUSIONS}

In post-Medieval western Europe, geographical, social and register variation persist in the written language. I have drawn on research into a small variety of languages; similar arguments have been put forward in studies on Danish, French, Finnish, Irish, Lithuanian, Scottish, etc (see a.o. Meurman-Solin 2000, Martineau 2007, Nordlund 2007, Sandersen 2007, McCafferty and Amador 
Moreno 2012, Klippi 2013, Tamošiūnaitè 2013). The variation found in the sources cannot always be explained away by referring to the gradual implementation of the standard language. Instead, there were regional writing practices, some of which were opposite to what is usually considered standard. This means that also for post-Medieval times, we have to reckon with various instances of supralocalization, and that the prototypically Medieval phenomenon of regional variation in the written languages existed well into modern times. As a consequence, it is unclear to what extent what we in hindsight would be tempted to call the standard was in fact regarded as such by language users in the past.

In addition, prescriptivists did not always agree on the preferred prescriptions and proscriptions. Normative publications were also not always targeted towards the general public. The social reach of language norms was usually fairly limited up until the second half of the eighteenth century, and it has been argued that sociolinguistic space was more complex than a simple one-way traffic from prescription to usage. In fact, the effects of prescriptivism are still quite uncertain, and there is not much evidence of clearly defined influence across the board (Rutten, Vosters and Vandenbussche 2014).

The conclusion to be drawn from all this is that it is uncertain to what extent the criteria for standard languages as developed in Auer $(2005,2011)$ are applicable to the history of European languages. Instead, diaglossia as developed in Auer $(2005,2011)$ is a very useful concept to describe the varietal spectrum available to language users at a given place and time, and should be applied to language history as much as to present-day situations. Related concepts from the historical sociolinguistic research tradition are supralocalization and intended supralocal variety, where the first refers to the course of individual variants, while the second addresses the functional aims of language users. What is crucial on the observational level, is that history provides us with numerous documents set in a language that is neither dialectal nor standard, a language that could therefore be characterized as intermediate, signaling a diaglossic repertoire. 
Diaglossia and supralocalization bear resemblances to processes of koineization and standardization. In fact, intermediate forms, and variation in language history in general, have also been addressed within a koineization framework (e.g. Tuten 2003; Howell 2006), whose prime goal is to explain language change, and particularly the focusing of multiple variants, as a result of contact between speakers. The formation of a new koine is a phenomenon that takes place in spoken interactions, where interpersonal accommodation is crucial at the micro-level (Tuten 2003: 28-29, 257). Obviously, this may leave traces in the written language. Koineization typically occurs in new towns and colonies due to major demographic changes, and in the absence of norm enforcing social networks (Tuten 2003: 90). In post-Medieval western Europe, migration was a common phenomenon, and the growth of many cities can only be explained with reference to mass immigration (Howell 2006). This means that intermediate forms in diaglossic repertoires may be the result of koineization. However, the supralocalization of specific forms also occurs in less turbulent times (Tuten 2003: 80-84), and strong writing traditions already existed in Medieval Europe. Diaglossia seems to be an appropriate descriptive label for complex dialect/standard constellations with many intermediate forms, while supralocalization identifies the individual trajectories of linguistic variants. Whether or not forms supralocalize in the written language as a result of koineization in the spoken language, needs to be established for each variant in itself with reference to relevant socio-historical changes.

Deumert and Vandenbussche (2003: 456) consider the interaction between 'pre-existing language standards and the emerging standard language' one of the most important research goals in standardization studies. Following Auer (2005, 2011), the question would be at what point in time the three criteria for a standard language have been sufficiently met. Much of the literature reviewed here suggests that the post-Medieval period should be thought of as one of diaglossia. The standardization model proposed in Nevalainen and Tieken-Boon van Ostade (2006) states that standardization is preceded by supralocalization, but it should be stressed that a plurality of supralocalizing forms is not just an apt description of the Middle English, Middle 
Dutch, Middle High German etc periods. The multiple and flexible normative points of orientation characteristic of supralocalization extend well into the modern period, and help explain patterns of variation in the seventeenth and eigtheenth centuries, and building on Elspaß (2005), Fairman (2007a, 2007b), McColl Millar (2012), A. Auer (2014) and others, also in the nineteenth century.

I have argued that diaglossia is the keyword when describing not just sociolinguistic situations in Europe in the present, but also when looking back on the twentieth, nineteenth, eighteenth, etc centuries. Moreover, Nevalainen (2012) argues that the rise of an English standard-like spelling between 1400 and 1600 began with various supralocal varieties, a situation that she describes as diaglossic, which only later gave way to diglossia in the sense of a single endoglossic spelling standard roofing the spoken dialects. This means that diaglossia should be extended even further back in time. If these historical periods were indeed diaglossic, the question of the interaction between supralocalized forms and/or varieties and general standard languages becomes all the more pressing. Has diaglossia ever given way to a situation with a welldefined standard language, 'orientated to by speakers of more than one vernacular variety', 'looked upon as an H-variety and used for writing' and 'subject to at least some codification and elaboration' (section 2)? The answer lies in acknowledging that diaglossia and supralocalization on the one hand, and standardization on the other, are concepts of a very different kind. Supralocalization refers to the use of specific variants outside their region of origin. Diaglossia refers to community repertoires with (bundles of) variants that are neither strictly dialectal nor standard. As such, supralocalization and diaglossia are generalizations over empirical and quantifiable results. Standardization, on the contrary, is an ideology, and a standard language is 'an idea in the mind rather than a reality' (Milroy and Milroy 2012: 19). While the Milroys argued for this ideological view of standardization in the context of the present-day spoken language, where 'a good deal of variety is tolerated in practice' (2012: 18), the evidence presented here suggests that the written language of the past was also not so 'fixed and invariant' that it can 
'properly be called the standard language' (2012: 18). This means that diaglossia may be the best description of the linguistic situation in post-Medieval times, which has given way to an ideal of standardization without, however, losing its empirical applicability. When exactly the ideal of a uniform standard language used and understood by all members of a specific community came about, is an empirical question. As suggested above (section 3.3), a crucial phase was probably the second half of the eighteenth century, when languages developed into symbolic markers of the newly formed modern European nation-states. As a consequence, the typological and historical development from diglossia to diaglossia (Auer 2005, 2011) should perhaps be turned upside down (cf. Nevalainen 2012). Diaglossia is the historical state of the written language, which became ideologically accompanied and/or replaced by the ideal of diglossia, that is, by the ideal of a uniform standard language that reduces all other variants and varieties to non-standardness. A final remark concerns the feasibility of the concept of diaglossia in the absence of a standard language. It could be argued that where there is no uniform standard language roofing other varieties, it does not make sense to talk about intermediate varieties, as there is no space in between. The historical sociolinguistic literature is not unanimous on this topic. The main point is that there were multiple points of normative orientation, which could deviate from what is usually considered standard. For some languages in some periods, it might seem appropriate to abandon the idea of a standard altogether. For many languages in post-Medieval Europe, however, the idea of a standard language might also be maintained, as long as we acknowledge that it is first and foremost an idea and an ideal, and that empirical research of language use has shown that neither the idea nor the ideal were necessarily shared by the language community at large, let alone adhered to in writing.

\section{NOTES}

1. This paper elaborates and details some of the ideas developed in Gijsbert Rutten, Rik Vosters and Wim Vandenbussche, 'The interplay of language norms and usage patterns. Comparing the 
history of Dutch, English, French and German', in Gijsbert Rutten, Rik Vosters and Wim Vandenbussche (eds.), Norms and usage in language history, 1600-1900. A sociolinguistic and comparative perspective. Amsterdam and Philadelphia, 2014: Benjamins, pp. 1-17. I thank Simon Pickl (Augsburg), Rik Vosters (Brussels), the editors and two anonymous reviewers for useful comments on an earlier draft.

2. As stated in the introduction, exoglossic norms were also part of the sociolinguistic situation. These often influenced codifications even in the Early and Late Modern period. Nevalainen (2012: 132), for example, points out that Latin and French spelling conventions left their marks on the incipient endoglossic standards of English. In Dutch, Latin-based morphological norms including four to six cases were prescribed well into the nineteenth century, despite the loss of inflection that had already set in in the medieval period (e.g. Simons and Rutten 2014).

\section{REFERENCES}

Altendorf, Ulrike. 2003. Estuary English. Levelling at the interface of RP and south-eastern British English. Tübingen: Gunter Narr Verlag.

Androutsopoulos, Jannis (ed.). 2006. Sociolinguistics and computer mediated communication. Theme issue Journal of Sociolinguistics 10/4.

Auer, Anita. 2014. Nineteenth-century English. Norms and usage. In Gijsbert Rutten, Rik Vosters and Wim Vandenbussche (eds.) Norms and Usage in Language History, 1600-1900. A Sociolinguistic and Comparative Perspective. Amsterdam and Philadelphia: Benjamins. 151-169.

Auer, Peter. 2005. Europe's sociolinguistic unity, or: A typology of European dialect/standard constellations. In Nicole Delbecque, Johan Van der Auwera and Dirk Geeraerts (eds.), Perspectives on Variation: Sociolinguistic, Historical, Comparative. Berlin: De Gruyter. 7-42.

Auer, Peter. 2011. Dialect vs. standard: A typology of scenarios in Europe. In Bernd Kortmann and Johan van der Auwera (eds.), The Languages and Linguistics of Europe. Berlin: De Gruyter. 485-500.

For review only. Confidential. Should not be cited. 
Ayres-Bennett, Wendy. 2014. From l'usage to le bon usage and back. Norms and usage in seventeenth-century France. In Gijsbert Rutten, Rik Vosters and Wim Vandenbussche (eds.) Norms and Usage in Language History, 1600-1900. A Sociolinguistic and Comparative Perspective. Amsterdam and Philadelphia: Benjamins. 173-200.

Beal, Joan. 2004. English in Modern Times, 1700-1945. London: Hodder Arnold.

Biber, Douglas and Susan Conrad. 2009. Register, Genre, and Style. Cambridge: Cambridge University Press.

Burke, Peter. 2004. Languages and Communities in Early Modern Europe. Cambridge: Cambridge University Press.

Deumert, Ana and Wim Vandenbussche. 2003. Research directions in the study of language standardization. In Ana Deumert and Wim Vandenbussche (eds.), Germanic Standardizations, Past to Present. Amsterdam and Philadelphia: Benjamins. 461-476.

Dossena, Marina. 2012. The study of correspondence: Theoretical and methodological issues. In Marina Dossena and Gabriella Del Lungo Camiciotti (eds.), Letter Writing in Late Modern Europe. Amsterdam and Philadelphia: Benjamins. 13-30.

Elspaß, Stephan. 2005. Sprachgeschichte von Unten. Untersuchungen zum Geschriebenen Alltagsdeutsch im 19. Jahrbundert. Tübingen: Niemeyer.

Elspaß, Stephan. 2007. 'Everyday language' in emigrant letters and its implications for language historiography: The German case. Multilingua 26: 151-165.

Elspaß, Stephan. 2012. The use of private letters and diaries in sociolinguistic investigation. In Juan M. Hernández-Campoy and Juan C. Conde-Silvestre (eds.), The Handbook of Historical Sociolinguistics. Malden, MA and Oxford: Wiley-Blackwell. 156-169.

Elspaß, Stephan. 2014. Prescriptive norms and norms of usage in nineteenth-century German. In Gijsbert Rutten, Rik Vosters and Wim Vandenbussche (eds.) Norms and Usage in Language History, 1600-1900. A Sociolinguistic and Comparative Perspective. Amsterdam and Philadelphia: Benjamins. 303-320.

For review only. Confidential. Should not be cited. 
Fairman, Tony. 2007a. Writing and 'the Standard': England, 1795-1834. Multilingua 26: 167-201.

Fairman, Tony. 2007b. 'Lower-order' letters, schooling and the English language, 1795 to 1834. In Stephan Elspaß, Nils Langer, Joachim Scharloth and Wim Vandenbussche (eds.) Germanic Language Histories 'from Below' (1700-2000). Berlin: De Gruyter: 31-43.

Fens-de Zeeuw, Lyda. 2011. Lindley Murray (1745-1826), Quaker and Grammarian. Utrecht: LOT. Haugen, Einar. 1966. Dialect, language, nation. American Anthropologist 68. 922-935.

Henstra, Froukje. 2014. Horace Walpole and his Correspondents. Social Network. Analysis in a Historical Context. Utrecht: LOT.

Hickey, Raymond (ed.). 2010. Eighteenth-Century English: Ideology and Change. Cambridge: Cambridge University Press.

Hickey, Raymond. 2012. Supraregionalisation. In Laurel Brinton and Alexander Bergs (eds.), Historical Linguistics of English. Berlin: De Gruyter. 2060-2075.

Howell, Robert B. 2006. Immigration and koineisation: The formation of Early Modern Dutch urban vernaculars. Transactions of the Philological Society 104: 207-227.

Joseph, John E. 1987. Eloquence and Power. The Rise of Language Standards and Standard Languages. New York: Blackwell.

Klippi, Carita. 2013. Letters from Gaston B. A prisoner's voice during the Great War. In Marijke van der Wal and Gijsbert Rutten (eds.) Touching the Past. Studies in the Historical Sociolinguistics of Ego-Documents. Amsterdam and Philadelphia: Benjamins. 107-128.

Kloss, Heinz. 1967. 'Abstand languages' and 'Ausbau languages'. Anthropological Linguistics 9: 29_ 41.

Langer, Nils. 2014. Standard German in the eighteenth century. Norms and use. In Gijsbert Rutten, Rik Vosters and Wim Vandenbussche (eds.) Norms and Usage in Language History, 1600-1900. A Sociolinguistic and Comparative Perspective. Amsterdam and Philadelphia: Benjamins. 277-302.

For review only. Confidential. Should not be cited. 
Lodge, Anthony. 2013. Codification and reallocation in seventeenth-century Paris. Taal \& Tongval 65: 57-72.

Lodge, Anthony. 2014. Jacques-Louis Ménétra and his experience of the langue d'oc. In Gijsbert Rutten, Rik Vosters and Wim Vandenbussche (eds.) Norms and Usage in Language History, 1600-1900. A Sociolinguistic and Comparative Perspective. Amsterdam and Philadelphia: Benjamins. 201-221.

Martineau, France. 2007. Variation in Canadian French usage from the $18^{\text {th }}$ to the $19^{\text {th }}$ century. Multilingua 26: 203-227.

Martineau, France and Sandrine Tailleur. 2014. From local to supra-local. Hybridity in French written documents from the nineteenth century. In Gijsbert Rutten, Rik Vosters and Wim Vandenbussche (eds.) Norms and Usage in Language History, 1600-1900. A Sociolinguistic and Comparative Perspective. Amsterdam and Philadelphia: Benjamins. 223-247.

Marynissen, Ann. 1998. Van -(t)ke naar -(t)je. De oorsprong en verspreiding van het Nederlandse diminutiefsuffix -(t)je. Tijdschrift voor Nederlandse Taal- en Letterkunde 114: 252-269.

McCafferty, Kevin and Carolina P. Amador Moreno. 2012. 'I will be expecting a letter from you before this reaches you'. A corpus-based study of shall/will variation in Irish English correspondence. In Marina Dossena and Gabriella Del Lungo Camiciotti (eds.) Letter Writing in Late Modern Europe. Amsterdam and Philadelphia: Benjamins. 179-204.

McColl Millar, Robert. 2012. The problem of reading dialect in semiliterate letters. The correspondence of the Holden Family, 1812-16 and of Richard Taylor, 1840-51. In Marina Dossena and Gabriella Del Lungo Camiciotti (eds.) Letter Writing in Late Modern Europe. Amsterdam and Philadelphia: Benjamins. 163-177.

McLelland, Nicola. 2014. Language description, prescription and usage in seventeenth-century German. In Gijsbert Rutten, Rik Vosters and Wim Vandenbussche (eds.) Norms and Usage in Language History, 1600-1900. A Sociolinguistic and Comparative Perspective. Amsterdam and Philadelphia: Benjamins. 251-275. 
Meurman-Solin, Anneli. 2000. Change from above or from below? Mapping the loci of linguistic change in this history of Scottish English. In Laura Wright (ed.), The Development of Standard English 1300-1800. Cambridge: Cambridge University Press. 155-170.

Meyerhoff, Miriam. 2011. Introducing Sociolinguistics. $2^{\text {nd }}$ ed. London and New York: Routledge. Mihm, Arend. 1998. Arbeitersprache und gesprochene Sprache im 19. Jahrhundert. In Dieter Cherubim, Klaus J. Mattheier and Siegfried Grosse (eds.), Sprache und bürgerliche Nation. Berlin: De Gruyter. 282-316.

Milroy, James. 1992. Social network and prestige arguments in sociolinguistics. In K. Bolton and H. Kwok (eds.), Sociolinguistics Today. International Perspectives. London: Routledge. 146-162. Milroy, Lesley. 2002. Social networks. In J.K. Chambers, Peter Trudgill and Natalie SchillingEstes (eds.), The Handbook of Language Variation and Change. Oxford etc: Blackwell. 549_ 572.

Milroy, James and Lesley Milroy. 2012 [1985]. Aubority in Language. Investigating Standard English. Abingdon and New York: Routledge.

Milroy, James, Lesley Milroy and Sue Hartley. 1994. Local and supra-local change in British English: The case of glottalisation. English World-Wide 15: 1-32.

Nevala, Minna. 2004. Address in Early English Correspondence. Its Forms and Socio-Pragmatic Functions. Helsinki: Socíeté Néophilologique.

Nevalainen, Terttu. 2012. Variable focusing in English spelling between 1400 and 1600. In Susan Baddeley and Anja Voeste (eds.) Orthographies in Early Modern Europe. Berlin: De Gruyter. $127-165$.

Nevalainen, Terttu. 2014. Norms and usage in seventeenth-century English. In Gijsbert Rutten, Rik Vosters and Wim Vandenbussche (eds.) Norms and Usage in Language History, 16001900. A Sociolinguistic and Comparative Perspective. Amsterdam and Philadelphia: Benjamins. 103-128.

For review only. Confidential. Should not be cited. 
Nevalainen, Terttu and Helena Raumolin-Brunberg. 2003. Historical Sociolinguistics. Language Change in Tudor and Stuart England. London etc: Longman.

Nevalainen, Terttu and Helena Raumolin-Brunberg. 2012. Historical sociolinguistics: Origins, motivations, and paradigms. In Juan M. Hernández-Campoy and Juan C. Conde-Silvestre (eds.), The Handbook of Historical Sociolinguistics. Malden, MA and Oxford: Wiley-Blackwell. $22-40$.

Nevalainen, Terttu and Ingrid Tieken-Boon van Ostade. 2006. Standardisation. In Richard Hogg and David Denison (eds.), A History of the English Language. Cambridge: Cambridge University Press. 271-311.

Nobels, Judith. 2013. (Extra) Ordinary letters. A View from Below on Seventeenth-Century Dutch. Utrecht: LOT.

Nordlund, Taru. 2007. Double diglossia - lower class writing in $19^{\text {th }}$-century Finland. Multilingua 26: $229-246$.

Osselton, N.E. 1984. Spelling systems in Early Modern English: 1500-1800. In N.F. Blake and Charles Jones (eds), English Historical Linguistics. Studies in Development. Sheffield: Centre for English Cultural Tradition and Language. 123-137.

Poplack, Shana, Lidia-Gabriela Jarmasz, Nathalie Dion and Nicole Rosen. 2015. Searching for Standard French: The construction and mining of the Recueil historique des grammaires $d u$ français. Journal of Historical Sociolinguistics 1: 13-55.

Rutten, Gijsbert. 2012. 'Lowthian’ linguistics across the North Sea. Historiographia Linguistica 39: 43-59.

Rutten, Gijsbert and Rik Vosters. 2013. Une tradition néerlandaise? Du bon usage aux Pay-Bas (1686-1830). In Wendy Ayres-Bennett and Magali Seijido (eds.), Bon Usage et Variation Sociolinguistique. Perspectives Diachroniques et Traditions Nationales. Lyon: ENS Éditions. 233244.

For review only. Confidential. Should not be cited. 
Rutten, Gijsbert, Rik Vosters and Wim Vandenbussche (eds.). 2014. Norms and Usage in Language History, 1600-1900. A Sociolinguistic and Comparative Perspective. Amsterdam and Philadelphia: Benjamins.

Rutten, Gijsbert and Marijke van der Wal. 2014. Letters as Loot. A Sociolinguistic Approach to Seventeenth- and Eighteenth-Century Dutch. Amsterdam and Philadelphia: Benjamins.

Sairio, Anni. 2009. Language and Letters of the Bluestocking Network. Sociolinguistic Issues in EighteenthCentury Epistolary English. Helsinki: Socíeté Néophilologique.

Sandersen, Vibeke. 2007. Writing ability and the written language of Danish private soldiers in the Three Years' War (1848-1850). Multilingua 26: 247-278.

Schlobinski, P. 2005. Mündlichkeit/Schriftlichkeit in den Neuen Medien. In L.M. Eichinger and W. Kallmeyer (eds.), Standardvariation. Wie viel Variation verträgt die deutsche Sprache?. Berlin: De Gruyter. 126-142.

Simons, Tanja and Gijsbert Rutten. 2014. Language norms and language use in eighteenthcentury Dutch. Final $n$ and the genitive. In Gijsbert Rutten, Rik Vosters and Wim Vandenbussche (eds.) Norms and Usage in Language History, 1600-1900. A Sociolinguistic and Comparative Perspective. Amsterdam and Philadelphia: Benjamins. 49-72.

Tamošiūnaité, Aurelija. 2013. Ego-documents in Lithuanian. Orthographic identities at the turn of the twentieth century. In Marijke van der Wal and Gijsbert Rutten (eds.) Touching the Past. Studies in the Historical Sociolinguistics of Ego-Documents. Amsterdam and Philadelphia: Benjamins. 225-242.

Tieken-Boon van Ostade, Ingrid. 2011. The Bishop's Grammar. Robert Lowth and the Rise of Prescriptivism. Oxford: Oxford University Press.

Tieken-Boon van Ostade, Ingrid. 2014. Eighteenth-century English normative grammars and their readers. In Gijsbert Rutten, Rik Vosters and Wim Vandenbussche (eds.) Norms and Usage in Language History, 1600-1900. A Sociolinguistic and Comparative Perspective. Amsterdam and Philadelphia: Benjamins. 129-150. 
Tuten, Donald N. 2003. Koineization in Medieval Spanish. Berlin and New York: De Gruyter.

Vandenbussche, Wim. 2004. Triglossia and pragmatic variety choice in 19th century Flanders. A case study in historical sociolinguistics. Journal of Historical Pragmatics 5: 27-47.

Vosters, Rik and Vandenbussche, Wim. 2012. Bipartite negation in 18th and Early 19th Century Southern Dutch: Sociolinguistic aspects of Norms and Variation. Neuphilologische Mitteilungen 103: 353-374.

Vosters, Rik, Els Belsack, Jill Puttaert and Wim Vandenbussche. 2014. Norms and usage in nineteenth-century Southern Dutch. In Gijsbert Rutten, Rik Vosters and Wim Vandenbussche (eds.) Norms and Usage in Language History, 1600-1900. A Sociolinguistic and Comparative Perspective. Amsterdam and Philadelphia: Benjamins. 73-100.

For review only. Confidential. Should not be cited. 